\title{
THE USE OF SWOT ANALYSIS METHODOLOGY FOR COMPLEX EVALUATION OF ENTERPRISES' CLUSTER ASSOCIATION DEVELOPMENT UNDER GLOBALIZATION
}

\author{
Olga Galtsova ${ }^{1}$, Tetiana Pulina², Oleh Holovko
}

\begin{abstract}
The article grounds the use of SWOT analysis methodology for complex evaluation of conditions for enterprises' cluster association development. It determines the factors that affect significantly food enterprises'cluster association development: the legal basis and norms regulating the activities of enterprises' cluster; attractiveness of the field and the level of competition in the sphere cluster enterprises belong to; benefits and threats from foreign environment regarding the cluster's activity; strengths and weaknesses of cluster association's member enterprises, their competitive opportunities; the availability of cluster structure development strategy; corporate culture type. It suggests the coefficient of level of SWOT analysis matrix margins influence on enterprises' cluster association activities. The research results state that the level of SWOT analysis "SO" matrix margin influence on dairy industry cluster association is $\mathbf{0 . 7 3}$. It proves a significant level of this quadrant impact on enterprises' cluster. The level of SWOT analysis ST matrix margin influence on dairy field cluster association is 0.34 . It proves that there is an average level of this quadrant impact on enterprises' cluster. The level of SWOT analysis "WO" matrix margin influence on dairy field cluster association is 0.09. It underlines an insignificant level of this quadrant influence on enterprises' cluster. Yet, the level of SWOT analysis WT matrix margin influence on dairy industry cluster association (-0.39) is of great importance and emphasizes the threatening influence of this quadrant on enterprises' cluster. The results of the conducted research due to SWOT analysis method are taken into account while developing the strategy of food enterprises' cluster association development. The strategy of concentrated growth is chosen for dairy field cluster, in particular the strategy of strengthening positions in the market and the strategy of market development.
\end{abstract}

Key words: SWOT analysis, cluster association of the enterprises, enterprises of the food industry.

JEL Classification: C38, P13

\section{Introduction}

In the context of globalization, the national economies of most industrialized countries have been transferred to cluster development models. In the food industry, cluster associations of enterprises have been established in many countries around the world. The most famous of these operate in the Northeastern United States, Canada and Western Europe. In the post-Soviet territories, the creation of clusters in the food industry is given considerable attention at the state level. State programs for the development of cluster initiatives, including in the food industry, have been created in Ukraine, Russia, and Kazakhstan. However, despite state support, the development of

Corresponding author:

${ }^{1}$ Classical Private University, Ukraine.

E-mail: olgagaltsova67@gmail.com

ORCID: https://orcid.org/0000-0003-0012-0371

2 “Zaporizhzhia Polytehnic” National University, Ukraine.

E-mail: pulinatv@ukr.net

ORCID: https://orcid.org/0000-0001-9159-5094

${ }^{3}$ Black Sea Research Institute of Economy and Innovation, Ukraine.

E-mail: o.p.golovko@gmail.com

ORCID: https://orcid.org/0000-0003-0841-4534 cluster structures is to some extent hindered by the lack of a unified approach to a complex evaluation of the conditions for the enterprises' cluster association development and, as a result, many cluster projects remain unrealized.

\section{Actual scientific researches and issues analysis and the research objective}

Certain issues of creation and functioning of enterprises cluster associations are covered in the works by Ukrainian and foreign scientists, in particular, M. Voinarenko, O. Pietukhova, M. Porter, T. Toguzaev etc. (Voinarenko, 2011; Pietukhova, 2012; Porter, 
1993; Toguzaev, 2009). These reasearches are of great scientific value but they cover only the issues of individual functions and components of the creation and development of cluster associations of enterprises. However, systemic research for complex evaluation of the conditions for the development of cluster associations of food industry enterprises has not been carried out.

The purpose of the study is to justify the use of SWOT analysis methodology for complex evaluation of conditions of enterprises' cluster association development.

\section{Cluster development tools at the regional level}

The development of market relations, the globalization of the world economy and the growth of competition, the creation of new forms of integration of enterprises, namely enterprises' cluster associations, revealed a number of theoretical and practical problems associated with the formation and selection of effective ways to develop new entities of organizational and economic relations.

Among the factors that significantly affect the development of cluster associations of food industry enterprises, the following should be noted:

- legal framework and regulations governing the activities of cluster enterprises;

- attractiveness and level of competition in the industry to which the production enterprises of the cluster belong;

- opportunities and threats from the external environment regarding the cluster activities;

- strengths and weaknesses of cluster enterprises, their competitive advantages;

- the presence of a strategy for the development of the cluster structure (Pulina, 2013).

We consider the prerequisites for the development of a cluster association of enterprises in the dairy subindustry of the food industry of Zaporizhzhia region.

In Ukraine, there are two documents regulating the creation and operation of clusters: "Draft Concept of the National Strategy for the Formation and Development of Cross-Border Clusters", approved by the Board of the Ministry of Regional Development and Construction of Ukraine No. 46 dated September 17, 2009 (Rishennia kolehii Ministerstva rehionalnoho rozvytku ta budivnytstva Ukrainy), and Resolution of the Presidium of NAS of Ukraine "On the Formation and Functioning of Innovation Clusters in Ukraine" No. 220 dated July 8, 2009 (Postanova Prezydii NAN "Pro formuvannia ta funktsionuvannia innovatsinykh klasteriv v Ukraini”).

The strategic goal of the development of food industry enterprises in Zaporizhzhia region is to form a structure that would meet the available natural resources and production potentials, as well as meet the needs of the population in food.

However, the current legislation of Ukraine does not provide for effective measures to support local producers (lack of tax benefits or tax holidays, lack of access to financial and credit resources, preferential lending rates, and complex licensing system) and increase consumer motivation to buy local products.

The strengths of the development of production and processing in the Zaporizhzhia region are: high level of natural resource potential and raw material base; branched industry structure; high level of urbanization, industrialization and per capita income as a prerequisite for increasing the capacity of the domestic market (Shmygol, Galtsova, Varlamova, 2018).

The weaknesses are: disproportions between raw materials and processing industries of the region; insufficient funding, limited logistics and inadequate technological renewal of enterprises in the industry; excessive share in the structure of production of certain types of foodstuff, including beverages; belonging of the region to the zone of extreme agriculture, associated with a negative moisture balance, periodic (every 3-4 years) droughts and frequent dust storms; the severity of the problem of preservation and restoration of the natural fertile layer of arable land; employment of a significant number of employees of the industry in conditions that do not meet sanitary and hygienic standards (1317 people, or $7.64 \%$ of the registered number of full-time employees of the food industry and processing of agricultural products in 2019).

At present in Zaporizhzhia region there are the following opportunities for the development of agroindustrial complex: increasing the productivity and efficiency of the regional agro-industrial complex; growth of the pace and expanding the vectors of attracting foreign investment; improvement of investment activity of enterprises; providing state support to privatized enterprises; development of separate enterprises of the food industry by means of the state target programs; expansion of export opportunities of enterprises of the food industry at the expense of growth of manufacture of the products, on the average on one person, at the level of world standards.

Expansion of the domestic market of the industry in the region is possible in the presence of a high level of industrialization (the share of industry in the structure of gross value added of the region in 2019 is $41.9 \%$ ); high level of urbanization (share of urban population in $2019-79.4 \%$ ); high level of average wages of industrial workers (in 2019 - 13649 UAH, third place in Ukraine) (Statystychnyi shchorichnyk Zaporizkoi oblasti za 2019 rik).

Threats to the development of the industry in the region are: unprofitable activities of private enterprises; reducing the profitability of agricultural enterprises; 
underdeveloped infrastructure of agricultural and food markets; imperfection of the food sales system; significant tax pressure; low rates of innovative restructuring of enterprises in the industry.

A necessary condition for the development of a cluster association of food industry enterprises in the long run is the presence of an effective development strategy.

Ansoff I. argues that strategy is a set of rules for decision-making, which the organization is guided in its activities (Ansoff, 1989).

According to Vykhanskyi O.S., reference business development strategies include:

- concentrated growth strategies related to product change and (or) market;

- integrated growth strategies related to the expansion of the organization by adding new structures;

- diversification growth strategies are recommended in situations where the organization can no longer develop in this market with this product within this industry;

- reduction strategies, which are used in situations where the organization ceases operations, restructures the boundaries of doing business or increases efficiency (Vikhanskii, 2002).

\section{Evaluation of the enterprises' cluster association using the methodology of SWOT analysis}

To justify the choice of the optimal strategy for the development of the enterprises' cluster project associations in the dairy industry of Zaporizhzhia region, we use the method of comprehensive analysis of the strengths and weaknesses of enterprises' cluster associations, their competitive opportunities and threats from the external environment using SWOT analysis (Vikhanskii, 2002; Holovko, Sahova, 2002; Mishchenko, 2004; Redchenko, 2003; Saienko, 2006; Thompson, Strickland, 1998).
Table 1 shows coefficients of the level of impact of the matrix fields of SWOT analysis on the activities of enterprises cluster associations.

By means of SWOT-analysis it is established that the project of cluster association in the dairy industry of Zaporizhzhia region has a number of strengths and opportunities in this market. We can offer specific strategies with the positioning of these parties and opportunities, taking into account and limiting the impact of weaknesses and threats, which will provide competitive advantages to the enterprises' cluster association.

Analysis of interrelations between opportunities and strengths cluster association project in the dairy industry of Zaporizhzhia region (SO field) allows to determine that for the effective use of such opportunities as the existing legal base of business, development of certain types of food industry by means of the state target programs, average rates of innovative reorganization of the enterprises of the industry, it is necessary to involve organizational structure adequate to cluster association purposes, the availability of certain opportunities in key activity, the developed production technology, a stable financial position of the cluster enterprises and significant sales volumes. In addition, the emergence of opportunities of external environment, such as increasing social needs, reorientation of life values, speed of change and adaptation of innovative technologies, new technological solutions in food production, improving the quality of existing food, increasing the pace and expanding areas of foreign investment, will provide additional benefits in the presence of such strengths of the cluster association as a highly professional team of employees, low employee turnover, a wide range of products, the ability to respond quickly to changes in consumer demand in general, as well as specific orders.

It should be noted that such strengths as highly qualified employees, incentive pay plan, stable and

Table 1

Method of calculating the coefficients of the impact of matrix fields of SWOT analysis on the activities of enterprises' cluster associations

\begin{tabular}{|c|c|c|}
\hline & Opportunities (O) & Threats $(\mathrm{T})$ \\
\hline Strengths $(S)$ & $\mathrm{C}_{\mathrm{SO}}=\frac{\sum_{i=1}^{m}\left( \pm D_{S O}\right)}{18 \cdot m}$ & $\mathrm{C}_{\mathrm{ST}}=\frac{\sum_{i=1}^{m}\left( \pm D_{S T}\right)}{18 \cdot m}$ \\
\hline Weak nesses (W) & $\mathrm{C}_{\mathrm{wO}}=\frac{\sum_{i=1}^{m}\left( \pm D_{W O}\right)}{18 \cdot m}$ & $\mathrm{C}_{\mathrm{WT}}=\frac{\sum_{i=1}^{m}\left( \pm D_{W T}\right)}{18 \cdot m}$ \\
\hline \multicolumn{3}{|c|}{$\begin{array}{l}\text { Where: } \\
\mathrm{D} \text { is evaluation of the matrix cell; } \\
\mathrm{m} \text { is the number of cells in one matrix field; } \\
\text { The value of the coefficient of impact is positive: from } 0 \text { to } 0.35 \text { means a slight impact, from } 0.35 \text { to } 0.60 \text { is an average impact, from } 0.60 \text { to } \\
1.00 \text { is a significant impact. } \\
\text { The value of the coefficient of impact is negative: from } 0 \text { to } 0.35 \text { is a negative impact, from } 0.35 \text { to } 0.60 \text { is a threatening impact, from } 0.60 \text { to } \\
1.00 \text { is a destructive impact. }\end{array}$} \\
\hline
\end{tabular}


long-term relationships with suppliers, high customer service culture and efficient business will allow you to take advantage of such opportunities as the desired level of customer loyalty to the products of the enterprises of association, high sensitivity of buyers to advertising, favorable attitude of buyers to innovative decisions of the enterprises of association, long cooperation with suppliers, granting forms of payment and conditions of deliveries best for the enterprises of association, increasing control over separate suppliers.

At the same time, such strengths of the enterprises' cluster association as the presence of own production in the cluster enterprises, the positive image of the enterprises of the cluster association among the residents and region of a city and region, significant sales volumes, proven technology of product distribution, low trade margin (compared to competitors), the use of modern means of consumer incentives contribute to the use of such opportunities as limited ability of buyers to choose other sellers, high average wages of employees in Zaporizhzhia region, growing demand for foodstuff, increasing the financial capacity of the population and the share spent on food, low marketing activity of competitors and a significant barrier to entry into the target market.

The study of pairs located in the "WO" field leads to the following assumptions: weaknesses such as lack of development strategy, bureaucratic organizational culture, inefficient cost management, lack of funding for cluster development are related to the lack of strategic management of cluster development. In order to eliminate the above weaknesses, it is advisable to develop a cluster development strategy and use the following opportunities: effective legal framework for entrepreneurship, innovative development of certain food industries by means of state target programs, average rates of innovation restructuring, increasing the pace and expansion of foreign investment, speed changes and adaptations of new technologies.

Undoubtedly, such weaknesses as the lack of marketing department, insignificant use of modern methods of analysis and forecasting, insufficient provision of equipment of trade enterprises in the cluster in terms of number of modern requirements of retail sales, imperfect customer relationship management system, are associated with low marketing activities. To eliminate the above weaknesses, it is necessary to improve the management of marketing activities, justify the marketing strategy and use the following opportunities: new technological solutions in food production; improving the quality of existing foodstuff; favorable attitude of buyers to innovative solutions of business associations; low marketing activity of competitors; high level of average wages of employees in Zaporizhzhia region.

High degree of commitment of buyers to products of the enterprises' association, growth of the level of social needs of the population, reorientation of vital values, limited possibility of buyers in a choice of other sellers, growth of demand of the population for foodstuff, high sensitivity of buyers to advertising, insignificant entrance barrier to the target market contribute to the improvement of financing the development of cluster enterprises, gathering information for a comprehensive analysis and survey, purchase of modern software, provision of trade equipment of commercial enterprises in the cluster in the respective number and modern requirements of retail sales.

Weaknesses, such as the lack of necessary raw materials at cluster enterprises due to shortcomings in work with suppliers, imperfect customer relationship management system, violations of storage conditions and quality of raw materials, can be improved by using opportunities such as long-term cooperation with suppliers, provision of forms of payment and terms of delivery, increasing control over the conditions of storage of raw materials and over individual suppliers.

If the pair is in the "ST" field, the strategy should involve the use of organizational force to eliminate threats.

The analysis of the correlation between the company's strengths and threats to the environment leads to the introduction of the following recommendations.

The presence of such strengths as an adequate organizational structure, the availability of certain skills in key areas, proper training of employees, a highly professional team, will help to reduce the impact of threats such as political instability in Ukraine, slowing economic reforms, constant changes in legislation, tough tax policy, lack of control over compliance with antitrust laws.

Positive image of the enterprises of cluster association among the residents of city and region, a wide range of products, the ability to respond quickly to changes in consumer demand in general and specific orders in particular, proven product distribution technology, low staff turnover, incentive pay plan will help to avoid or reduce the impact of threats such as budget deficits, high inflation, reduced birth rate, growing supplier prices and reducing the number of suppliers who provide the necessary products for enterprises, increase in the number of active competitors.

The presence of such strengths as stable and long-term relationships with suppliers, stable financial position of cluster enterprises, increased profits, significant sales will help to avoid or reduce the impact of such threats as low customer satisfaction with products (services) of the enterprises' cluster association, increase in prices of suppliers, reducing the number of suppliers who provide the necessary products for enterprises and increasing the number of active competitors.

The impact of such factors as high unemployment, deteriorating demographic situation in the country, declining working population of Ukraine, reducing 
birth rate, low living standards, rising unemployment can be avoided due to the presence of own production in cluster enterprises, waste technology, low trade margin (as compared to competitors) and the use of modern means of consumer incentives.

For pairs in the "WT" field, the company must develop a strategy that eliminates weaknesses and prevents threats.

For pairs in the "WT" field, it should be noted that the risk of adverse external conditions may be exacerbated by the weakness of the relevant internal characteristics of the enterprises' cluster association.

The enterprises' cluster association can be negatively affected by a combination of such weaknesses as lack of development strategy, bureaucratic organizational culture, lack of necessary raw materials at cluster enterprises due to lack of work with suppliers, inadequate technological renewal of enterprises, lack of information for comprehensive analysis and survey threats such as the instability of the political situation in Ukraine, the slowdown in economic reforms, constant changes in legislation, budget deficits, low customer satisfaction with products (services) of the association, the emergence of new, stronger food companies in the cluster specialization.

In addition, the combination of threats such as increased supplier prices, reduced number of suppliers providing raw materials and goods necessary for cluster enterprises, increased number of active competitors, low living standards, with such weaknesses as lack of modern software, violation of storage conditions and quality of raw materials, inefficient cost management, improper use of modern methods of analysis and forecasting, is worthy of special attention.

In addition, it is worth paying attention to the combination of such threats that affect the enterprises' cluster association, as tough tax policy, lack of control over compliance with antitrust laws, inflation rate of $3-3.5 \%$, high unemployment rate of $2.4 \%$, trend reduction of the working population of Ukraine, reduction of birth rate, increase of unemployment, and such weaknesses as insufficient provision of equipment of trade enterprises in the cluster by number and modern requirements of retail sales, insufficient financing of cluster enterprises development, lack of marketing department and imperfect consumer relations management system (Statystychnyi shchorichnyk Zaporizkoi oblasti za 2019 rik).

That is why the management of the enterprises' cluster association should monitor and avoid threats with the help of existing strengths or, best of all, seek to get rid of weaknesses that may have a critical impact in the event of the above threats. Therefore, to reduce the impact of threats from the external environment and strengthen weaknesses, it is necessary to form a clear strategy for clustering companies, develop targeted product range policies, improve the organization of marketing activities and increase marketing budget.

Quantitative assessment of strengths and weaknesses, as well as threats and opportunities of clustering for each pair of the SWOT analysis matrix is possible from -18 to +18 . This interval is divided into six groups of values: (from -18 to -12 ); (from -11 to -6 ); (from -5 to 0 ); (from 1 to 5); (from 6 to 11 ); (from 12 to 18 ).

It is expedient to carry out the estimates of the impact of one pair of the SWOT matrix on the enterprises' association in Zaporizhzhia region on the following scale of values:

- if the estimates of interaction are (from - 18 to -12) and (from 12 to 18 such a pair has a significant negative or positive impact and these pairs should be given special attention;

- pairs of the SWOT analysis matrix according to the interaction estimates (from -11 to -6 ) and (from 6 to 11) show an average impact on the activity of the enterprises' association. According to the interaction estimates (from -5 to 0 ) and (from 1 to 5 ), pairs have a slight effect.

The final stage of estimating the factors of the impact of four fields of the SWOT analysis matrix on the cluster association is proposed to be carried out with the help of generalizing indicators - coefficients of influence of the fields of the SWOT analysis matrix on enterprises' associations.

$\mathrm{C}_{\mathrm{so}}$ is the coefficient of influence of the "SO" field of the SWOT analysis matrix on the enterprises' association, which is formed by the strengths of the cluster and opportunities from the external environment. The coefficient for the "SO" field $\mathrm{C}_{\mathrm{so}}$ is calculated by formula (1):

$$
\mathrm{C}_{\mathrm{so}}=\frac{\sum_{i=1}^{m}\left( \pm D_{\mathrm{so}}\right)}{18 \cdot m} ;
$$

where $D_{\text {so }}$ is the value of estimates of the strength of the cluster and opportunities from the external environment for each cell of the SWOT analysis matrix on the enterprises' association of Zaporizhzhia region;

$\mathrm{m}$ is the number of cells in one field of the SWOT analysis matrix of the enterprises' associations.

$$
\mathrm{C}_{\mathrm{so}}=\frac{5857}{18 \cdot 440}=0,74
$$

$\mathrm{C}_{\mathrm{wo}}$ the coefficient of the impact of the "SO" field of the SWOT analysis matrix on the enterprises' association, which is formed by the strengths of the cluster and opportunities from the external environment. The coefficient for the "WO" field $\mathrm{C}_{\mathrm{wo}}$ is calculated by formula (2):

$$
\mathrm{C}_{\mathrm{wo}}=\frac{\sum_{i=1}^{m}\left( \pm D_{W O}\right)}{18 \cdot m} ;(2)
$$

where $D_{\text {wo }}$ is the value of estimates of the weaknesses of the cluster and opportunities from the external 
environment for each cell of the SWOT analysis matrix on the enterprises' association;

$m$ is the number of cells in one field of the SWOT analysis matrix of the enterprises' associations.

$$
\mathrm{C}_{\text {wo }}=\frac{520}{18 \cdot 299}=0,10
$$

$\mathrm{C}_{\mathrm{ST}}$ is the coefficient of influence of the "ST" field of the SWOT analysis matrix on the enterprises' association, which is formed by the strengths of the cluster and threats from the external environment.

The coefficient for the "ST" field $\mathrm{C}_{\mathrm{ST}}$ is calculated by formula (3):

$$
\mathrm{C}_{\mathrm{ST}}=\frac{\sum_{i=1}^{m}\left( \pm D_{\mathrm{ST}}\right)}{18 \cdot m} \text {; } 3
$$

where $D_{\text {ST }}$ is the value of estimates of the strengths of the cluster and threats from the external environment for each cell of the SWOT analysis matrix on the enterprises' association;

$\mathrm{m}$ is the number of cells in one field of the SWOT analysis matrix of the enterprises' associations.

$$
\mathrm{C}_{\mathrm{ST}}=\frac{2333}{18 \cdot 360}=0,36
$$

The coefficient for the "WT" field $\mathrm{C}_{\mathrm{WT}}$ is calculated by formula (4):

$$
\mathrm{C}_{\mathrm{WT}}=\frac{\sum_{i=1}^{m}\left( \pm D_{W T}\right)}{18 \cdot m} \text {; (4) }
$$

where $D_{w T}$ is the value of estimates of the weaknesses of the cluster and threats from the external environment for each cell of the SWOT analysis matrix on the enterprises' association;

$\mathrm{m}$ the number of cells in one field of the SWOT analysis matrix of the enterprises' associations.

$$
\mathrm{C}_{\text {wT }}=\frac{-892}{18 \cdot 134}=-0,37
$$

It is expedient to carry out evaluation of the level of influence of the fields of the SWOT analysis matrix on the enterprises association of Zaporizhzhia region on such scale of coefficient values.

The value of the coefficient of impact is positive: from 0 to 0.35 - a slight impact, from 0.35 to 0.60 - an average impact, from 0.60 to 1.00 - a significant impact.

The value of the coefficient of the impact of the SWOT analysis matrix fields is negative: from 0 to 0.35 - a negative impact, from 0.35 to 0.60 - a threatening impact, from 0.50 to 1.00 - a destructive impact.

The analysis has shown that the impact of the "SO" field of the SWOT analysis matrix on the cluster association of the dairy industry is 0.73 . This indicates a significant level of influence of this quadrant on the enterprises' associations. The impact of the "ST" field of the SWOT analysis matrix on the cluster association of the dairy industry is 0.34 , which indicates the average impact of this quadrant on the association of enterprises. The level of influence of the "WO" field of the SWOT analysis matrix on the cluster association of the dairy industry is 0.09 , which confirms the slight impact of this quadrant on the association of enterprises. However, the level of influence of the "WT" field on the cluster association of the dairy industry $(-0.39)$ is negative and indicates the threatening impact of this quadrant on the enterprises' association of the dairy industry.

The results of the analysis by the SWOT method are taken into account when creating strategies for the development of the project of the enterprises' association in the dairy industry of Zaporizhia region.

\section{Strategic goals}

The strategy is seen as a model to which the cluster association seeks to approach. Most often, a thriving cluster is taken as a sample, its positive aspects of activity are analyzed and attempts are made to use its experience.

The strategy development process begins with the proclamation of the mission and goals of the enterprises' cluster association in the dairy industry of Zaporizhzhia region.

There are a number of actors that influence the mission of a cluster association:

- founders of the cluster association;

- employees of enterprises that are part of the cluster association (the realization of goals depends on the level of their qualification);

- consumers (the mission is focused on them, they determine the demand of goods and services);

- partnership relations among the members of the cluster association.

A mission is proposed to unite enterprises in the dairy industry of Zaporizhzhia region "We make the lives of our consumers better".

The most universal approach to the formulation of goals provides the principle of their establishment in accordance with internal functions (marketing, finance, production, personnel, structure).

This, the main objectives of the enterprises' cluster association in the dairy industry of Zaporizhzhia region meet the requirements of goal setting:

- to take on $75 \%$ of the regional dairy market in the next five years;

- to reduce the cost of production of enterprises of the cluster association due to the use of advanced equipment in the field of management and strategic marketing;

- to adhere to the motivational policy when working with the enterprises' employees, to involve highly qualified employees to work at the enterprises of the cluster association.

Defining short-term periods ( 5 years) for achievement of certain purposes and specification of ways to achieve the purposes characterize the purposes of the 
enterprises' cluster association of the food industry of Zaporizhzhia region as both dynamic and optimal.

For the cluster of dairy industry the concentrated growth strategies are selected: market position strengthening strategy and market development strategy.

The market position strengthening strategy requires significant marketing efforts in the field of product management, advertising, pricing and quality customer service.

If the market position strengthening strategy is followed, the enterprises of the cluster association try to improve their products or start producing new ones without changing the industry. As for the market development strategy, the cluster association is looking for opportunities to improve its position in the existing market or transition to a new market.

\section{Conclusions}

According to the results of research, the factors that significantly affect the development of the food industry enterprises' cluster association are defined and the use of SWOT analysis methodology for complex evaluation of conditions of the enterprises' cluster association development is justified.

The coefficients of impact of the SWOT analysis matrix fields of the activities of the enterprises' cluster association are suggested. Based on the values of the coefficients of impact of the SWOT analysis matrix fields of the activities of the enterprises' cluster association, the choice of project development strategy for cluster structure in the dairy industry is justified, namely, strategies of concentrated growth: market position strengthening strategy and market development strategy. The implementation of the market position strengthening strategy requires significant marketing efforts in the field of product management, advertising, pricing, quality customer service.

However, a long-term strategy cannot envisage all options for the development of the market situation, and competitive strategies need to be advanced to adjust the directions of development strategy implementation.

\section{References:}

Voinarenko, M. P. (2011). Klastery v instytutsiinii ekonomitsi: monohrafiia [Clusters in the institutional economy: a monograph]. Khmelnytskyi: KhNU, LLC Triada-M, 502 p.

Pietukhova, O. M. (2012). Klasteryzatsiia yak mozhlyvist realizatsii innovatsiinykh stratehii [Tekst]: monohrafiia [Clustering as an opportunity to implement innovative strategies [Text]: monograph]. Kyiv: NUFT, 263 p.

Porter, M. (1993). Mezhdunarodnaia konkurentciia [International competitiveness] [translated from English]. Moskow: International relations, 896 p.

Toguzaev, T. Kh. (2009). Klasternyi podkhod k strategicheskomu razvitiiu predpriiatii pishchevoi promyshlennosti [Cluster approach to the strategic development of food industry enterprises]. Izvestiia Sankt-Peterburgskogo universiteta ekonomiki i finansov, vol. 2, pp. 56-63.

Pulina, T. V. (2013). Informatsiine zabezpechennia stvorennia ta rozvytku klasternykh obiednan pidpryiemstv kharchovoi promyslovosti [Information support for the creation and development of cluster associations of food industry enterprises]. Business Inform, vol. 5, pp. 145-152.

Rishennia kolehii Ministerstva rehionalnoho rozvytku ta budivnytstva Ukrainy vid 17.09.2009. № 46. Proekt kontseptsii Natsionalnoi stratehii formuvannia ta rozvytku transkordonnykh klasteriv [Decision of the Board of the Ministry of Regional Development and Construction of Ukraine dated 17.09.2009. № 46. Draft concept of the National strategy for the formation and development of cross-border clusters]. Available at: http://search.ligazakon.ua/1_doc2.nsf/link1/FIN50039.html

Postanova Prezydii NAN "Pro formuvannia ta funktsionuvannia innovatsiinykh klasteriv v Ukraini" vid 08. lyp. 2009 r. № 220 [Resolution of the Presidium of the NAS "On the formation and functioning of innovation clusters in Ukraine” from July 08, 2009. № 220]. Available at: http://www.inno.kharkov.ua/wp-content/ uploads/2009/10/postanovl-nanu1.pdf

Shmygol, N., Galtsova, O., \& Varlamova, I. (2018). Developing a methodology to assess the environmental and economic performance index based on international research to resolve the economic and environmental problems of Ukraine. Baltic Journal of Economic, vol. 4, no. 4, pp. 366-375. doi: 10.30525/2256-0742/2018-44-366-374

Perevozova, I., Shmygol, N., Tereshchenko, D., Kandahura, K., \& Katerna, O. (2019). Introduction of creative economy in international relations: aspects of development security. Journal of Security and Sustainability, vol. 9(1), pp. 139-154. doi: 10.9770/jssi.2019.9.1(11)

Shmygol, N., Łuczka, W., Trokhymets, O., Pawliszczy, D., \& Zavgorodniy, R. (2020). Model of diagnostics of resource efficiency in oil and gas sector of economy of Ukraine. E3S Web of Conferences.

Shmygol, N., Galtsova, O., Solovyov, O., Koval, V., \& Arsawan, I. (2020). Analysis of country's competitiveness factors based on inter-state rating comparisons. E3S Web Conferences, 153, 03001. doi: 10.1051/ e3sconf/202015303001

Kostetska, K., Khumarova, N., Umanska, Y., Shmygol, N., \& Koval, V. (2020). Institutional qualities of inclusive environmental management in sustainable economic development. Management Systems in Production Engineering, vol. $28(2)$, pp. $15-22$. doi: $10.2478 / \mathrm{mspe}-2020-0003$ 
Statystychnyi shchorichnyk Zaporizkoi oblasti za 2019 rik [Statistical Yearbook of Zaporizhzhia region for 2019]. Zaporizhzhia: Main Department of statistics in Zaporizhzhia region, 2020. 473 p.

Ansoff, I. (1989). Strategicheskoe upravlenie [Strategic management]; translated from English; scientific editor and foreword author L. I. Evenko. Moskva: Ekonomika, 519 p.

Vikhanskii, O. S. (2002). Strategicheskoe upravlenie: uchebnik [Strategic management: textbook] [2nd ed., revised and enlarged]. Moskva: Gardariki, $296 \mathrm{p}$.

Holovko, T. V., \& Sahova, S. V. (2002). Stratehichnyi analiz: Navch.-metod. posibnyk dlia samost. vyvch. dysts. [Strategic analysis: Textbook-manual for self-study of the discipline]; edited by M. V. Kuzhelnyi, Doctor of Economic Scinces, Professor. Kyiv: KNEU, 198 p.

Mishchenko, A. P. (2004). Stratehichne upravlinnia: navch. posibnyk [Strategic management: training manual]. Kyiv: Tsentr uchbovoi literatury, 336 p. Available at: http://pidruchniki.ws/00000000/marketing/strategichne_ upravlinnya_-_mischenko_ap

Redchenko, K. I. (2003). Stratehichnyi analiz u biznesi: navch. posibnyk [strategic analusis in business: training manual] 2nd edition, enlarged. Lviv: "Novyi Svit-2000", "Altair-2002", 272 p.

Saienko, M. H. (2006). Stratehiia pidpryiemstva: pidruchnyk [Strategy of the enterprise: textbook]. Ternopil: Ekonomichna dumka, $390 \mathrm{p}$.

Thompson, A. A., \& Strickland, A. J. (1998). Strategicheskii menedzhment. Iskusstvo razrabotki i realizatcii strategii: uchebnik dlia vuzov [translated from English]. Moskva: Banki i birzhi, UNITI, 576 p. 